解説記事

植物遺伝資源を利用する研究者への名古屋議定書とその国内措置の影響

土門英司

国立研究開発法人農業・食品産業技術総合研究機構，遺伝資源センター，つくば市，干 305-8602

\title{
Impact of the Nagoya protocol on Access and Benefit-sharing and its domestic ABS measures of Japan on researchers in the field of plant breeding
}

Eiji Domon

National Agriculture and Food Research Organization, Genetic Resources Center, Tsukuba, Ibaraki 305-8602

キーワード

遺伝資源，生物多様性条約，ABS，名古屋議定書，国内措置，食料農業植物遺伝資源条約

\section{はじめに}

我が国は「生物の多様性に関する条約の遺伝資源の取 得の機会及びその利用から生ずる利益の公正かつ衡平な 配分に関する名古屋議定書」（The Nagoya Protocol on Access to Genetic Resources and the Fair and Equitable Sharing of Benefits Arising from their Utilization to the Convention on Biological Diversity，以下「名古屋議定書」 といら。）を2017年 5 月 22 日に受諾し, 同年 8 月 20 日か ら国内にその効力が発生した。 そ扎に伴い, 名古屋議定 書の義務を履行するために必要な国内措置が策定された. 今後, 我が国に沶いて, 食料農業植物遺伝資源条約の適 用対象ではない植物遺伝資源を名古屋議定書締約国から 入手し, 研究開発の目的で利用する場合掞よび育種事業 に利用する場合には，この国内措置に従う必要がある。

本稿の目的は, こうした状況の下で研究者の植物遺伝 資源の利用を支援し, 名古屋議定書とその国内措置を適 切に遵守する観点から, 名古屋議定書の諸規定と, それ に関係した我が国の新しい名古屋議定書を履行するため の国内措置の概要抢よびその留意点について解説するこ とにある。

\section{1. 名古屋議定書が発効するまでの経緯}

名古屋議定書は「生物の多様性に関する条約」 (Convention of Biological Diversity，CBD．以下「多様性 条約」という.）という生物の多様性に関する包括的な枠

2017 年 7 月 21 日受領

2018 年 1 月 22 日 J-STAGE 早期公開

Correspondence: domon@affrc.go.jp
組の中に位置付けられる議定書であり, 以下にその発効 に到るまでの経緯を述べる。

多様性条約は，1992 年 5 月に採択され，1993 年 12 月 に発効した。 2017 年現在，アメリカ合衆国等を除き，我 が国を含む196の国と欧州連合（EU）が加入している. 多様性条約は三つの目的を揭げて打り，それらは，1. 生 物の多様性の保全, 2. そ構成要素の持続可能な利用, 3. 遺伝資源の利用から生ずる利益の公正から衡平な配分 である。また，多様性条約第 15 条では，遺伝資源の取得 の機会の提供や利益の配分 (Access and Benefit-Sharing, 以下「ABS」という。）について規定している.

多様性条約第 15 条の下での ABS の実現に向けた協議 は 1995 年の多様性条約第 2 回締約国会合 (Conference of Parties，以下「COP」といら。）から行われて抢り，1998 年の COP4（スロバキア，ブラチスラバ）で設置が決定 された $\mathrm{ABS}$ 専門家パネル会合による協議の報告書 (United Nations Environment Programme 1999) は2000 年 の COP5（ケニア，ナイロビ）に送付された，COP5では 特別作業部会 (Ad Hoc Open-ended Working Group on Access and Benefit-sharing, ABS WG）の設置が決定され， 多様性条約第 15 条に従った ABS の方法に関するガイド ライン案を作成する権限が与えられた。翌 2001 年, 第 1 回 ABS WG（ドイッ，ボン）が開催され，その検討結果 はCOP6 に送付された。 2002 年 4 月の COP6（オランダ, ハーグ）では ABS WG の草案をもとに議論が行わ机，修 正の上「遺伝資源へのアクセスとその利用から生じる利 益の公正・から衡平な配分に関するボン・ガイドライン」 （以下「ボン・ガイドライン」という.）が採択された (United Nations Environment Programme 2002). ボン・ガ イドラインは多様性条約締約国に抢ける ABS のための制 度設計の支援を目的とする任意のガイドラインであり， 
各種の手続きについて具体性のある方法が例示された法 的拘束力を持たない国際文書である。

2002 年 8,9 月に開催された持続可能な開発に関する 世界首脳会議（ヨハネスブルグ・サミット）に打いて, 開発途上国はこのガイドラインの任意性を不服として法 的拘束力のある ABS のための国際的枠組みの必要性を主 張した。一方，先進国はボン・ガイドラインの実施直後 であり，まだボン・ガイドラインの成果はまだ判断でき ないことから新たな国際的枠組みの必要性は認められな いと主張した. 交渉の結果, 世界首脳会議の成果文書（持 続可能な開発に関する世界首脳会議実施計画）の一部に, ボン・ガイドラインを念頭に置きつつ多様性条約の枠組 又内で ABS のための法的拘束力を持つ国際的枠組又 （International Regime on ABS，以下「IR」という.）のた めの交渉開始を提起寸る内容が採択され，以降，多様性 条約の場でIR の交渉が開始されることとなった（United Nations 2002).

これを受けて，2004 年の多様性条約 COP7 では，ABS WG に括いて IR の草案の作成拉よび交渉を行っていくこ とが決定された（United Nations Environment Programme 2004）。しかし，国際的枠組久の性格や適用範囲等に関寸 る途上国と先進国の意見の隔たりは大きく, COP7 以降 の ABS WG に打ける交渉が難航したことから，2006 年 の COP8 では ABS WG に拈訬作業をCOP10 までに完 了することが決定された（United Nations Environment Programme 2006).

2008 年に開催された COP9（ドイッ，ボン）では, 2010 年に愛知県名古屋市に括いて COP10 開催することが正 式に決定された（United Nations Environment Programme 2008)。翌 2009 年に開催された第 8 回 ABS WG では, 各 国から提出された意見をもとに IR の草案が作成され， COP10 で採択する最終原案の作成に向けて作業を継続す ることとなった。第 8 回 ABS WG の成果文書である IR の草案 (United Nations Environment Programme 2009) に は非常に多くの意見の相違が残されていたが，2010年 3 月に開催された第 9 回 ABS WG では法的拘束力のある議 定書（protocol）として IR を構築することが合意され， 交渉を継続することとなった（United Nations Environment Programme 2010a).

しかし，それ以降 COP10 までの間に持たれた追加会合 と 2010 年 10 月の COP10 期間中に持たれた非公式協議 会合での集中的な交渉にもかかわらず，COP10 会期最終 日前日の深夜に至っても IR についての途上国と先進国の 意見の乘離は埋まらず，非公式協議会合での合意には至 らなかった，COP10 の議長を務めた松本龍氏は，非公式 協議会合共同議長からの報告を受け COP10 の会期最終 日にこれまで協議されてきた議定書の草案を全面的に書 き直した新議長案を各国に提示した。この新議長案に基 づいて閣僚レベルを含む非公式な調整が行われ，それに 基づく草案が「生物の多様性に関する条約の遺伝資源の
取得の機会及びその利用から生ずる利益の公正かつ衡平 な配分に関する名古屋議定書」として採択された（United Nations Environment Programme 2010b)。こうして2002 年 9 月のヨハネスブルグ・サミットを起点として 8 年間に 及ぶ協議は 2010 年 10 月の COP10をもって終結した.

COP10 で採択された名古屋議定書は同議定書の規定 に従って 2011 年 2 月 2 日から 2012 年 2 月 1 日まで国 連本部に捛いて署名のために開放され，50 番目の批准 書, 受諾書, 承認書または加入書の寄託の日の後 90 日目 に発効するとされた（United Nations Environment Programme 2010b). 同議定書の発効は, 50 番目のウルグ アイの批准から 90 日目にあたる 2014 年 10 月 12 日であ り, 名古屋議定書第 1 回締約国会議（COP-MOP1）は, 同年 10 月，COP12（韓国，ピョンチャン）の会期中の 13 日から 17 日にかけて開催された。

な拈, 名古屋議定書の発効後に同議定書に加入した締 約国に対しては，同議定書では批准等のための手続きか ら 90 日目に当該国について効力が発生することから 2014 年 10 月 12 日から効力が発生している.

\section{2. 名古屋議定書の概要}

名古屋議定書は多様性条約を枠組みとする国際的な ABS の仕組み（図 1）を実現するため, 議定書締約国に 対して法的な拘束力を持ち，国際的に協調しながら ABS の実現に必要な国内制度の整備を進める役割を持った国 際文書である。

名古屋議定書の主要な規定には，目的，用語，適用範 囲，他の国際条約との関係，遺伝資源の利用国の執る措 置汇関するもの，提供国の執る措置に関するものおよび， 提供国・利用国の双方が執る措置に関するもの等がある. 以下に名古屋議定書のこれらの主要な規定を紹介する.

\section{1 名古屋議定書の目的（第 1 条）}

名古屋議定書の目的は，遺伝資源の利用のための取得 の機会（アクセス）を確保し，その利用から得られる利 益の配分を技術移転や資金供与等を通じて行い，多様性 条約の目的の達成に貢献することとされている。

\section{2 名古屋議定書の用語（第 2 条）}

名古屋議定書で用いられる用語の使い方は，多様性条 約での用語の使い方に従う。この活か名古屋議定書で改 めて規定している用語は，「遺伝資源の利用」，「バイオテ クノロジー」抢よび「派生物」であり，それぞれ第 2 条 で次のように説明されている.

（c）「遺伝資源の利用」とは，遺伝資源の遺伝的および ／または生化学的な構成に関する研究打よび開発 を行うことをいう（多様性条約第 2 条に定義する バイオテクノロジーを用いて行うものを含む).

（d）多様性条約第 2 条に定義する「バイオテクノロ 


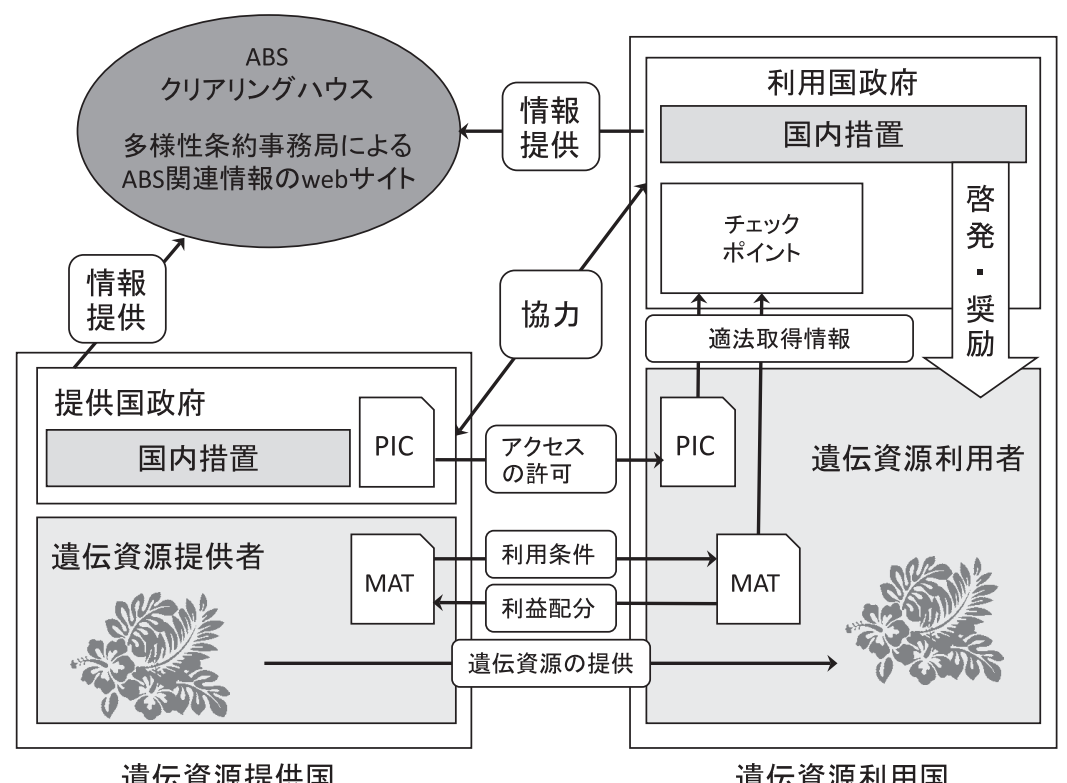

図 1. 名古屋議定書に基づく $\mathrm{ABS}$ の仕組みの概要

ジー」とは，物または方法を特定の用途のために 作り出し, または改変するため, 生物システム, 生物をたその派生物を利用寸る応用技術をいら。

（e）「派生物」とは，生物資源または遺伝資源の遺伝的 な発現または代謝の結果として生ずる生化学的化 合物（遺伝の機能的な単位を有していないものを 含む.）であって，天然に存在するものをいう。

上記の (c), (d), (e) について育種学分野の研究開発 と関連の深いものを例示すると，(c)「遺伝資源の利用」 には，作物の育種や品質に関する遺伝育種学分野の研究 開発や農芸化学分野の研究開発が含まれ，(d)「バイオテ クノロジー」には, 遺伝子組換兄技術の適用に上る研究 のための植物材料の開発, (e)「派生物」には, 植物由来 の二次代謝産物が含まれる。従って, ゲノム解析やメ夕 ボローム解析，遺伝子組換兄作物の開発は名古屋議定書 のこれらの定義上，遺伝資源の利用に該当することにな る.

\section{3 名古屋議定書の適用範囲（第 3 条）}

名古屋議定書の適用範囲は, 「(多様性) 条約第 15 条の 規定の範囲内の遺伝資源打よびその利用から生ずる利益」 および「遺伝資源に関連する伝統的な知識であって条約 の範囲内のもの拉よび当該伝統的な知識の利用から生ず る利益」とされている.

多様性条約第 15 条は遺伝資源の利用のための取得の 機会について定めており, 名古屋議定書第 3 条に従えば 多様性条約の発効以前からもともと締約国内にあった遺 伝資源や，多様性条約締約国ではない国（アメリカ合衆 国等）から締約国に導入された遺伝資源については名古 屋議定書の適用範囲には含まれていない.

また，後段の遺伝資源に関連する伝統的な知識の範囲
については，多様性条約の第 8 条（j）に規定するものが それ該当する。

なお，我が国では名古屋議定書の個別の条項の規定と は別に，遡及適用はされないといら法の原則が名古屋議 定書の国内措置にも当てはまることから, 名古屋議定書 が我が国に効力を発揮した日（2017 年 8 月 20 日）以前 から国内にあった遺伝資源や遺伝資源に関連する伝統的 な知識も名古屋議定書および国内措置の適用範囲には含 まれない。

\section{4 名古屋議定書と国際協定および国際文書との関係 (第 4 条)}

名古屋議定書第 4 条では, 名古屋議定書は基本的に他 の国際協定拉よび国際文書（条約等）の条件に影響を与 えないことなどの一般原則が述べられている．第 4 条第 3 項では「この議定書に関連する他の国際文書と相互に 補完的な方法で実施する」とされ，第 4 条第 4 項では, 名古屋議定書の適用対象の例外となる遺伝資源として他 の ABS 関連条約の締約国にある特定の遺伝資源について は「当該文書が対象とする特定の遺伝資源に関しては, 当該文書の適用のため, 当該文書の締約国については適 用しない」として除外している.

ここで言う他の国際文書に該当するものの解釈は締約 国に委礼られて和り，我が国では「食料及び農業のため の植物遺伝資源に関する国際条約」(International Treaty on Plant Genetic Resources for Food and Agriculture, ITPGR) や，世界保健機関（World Health Organization, WHO）が 新型インフルエンザの流行阻止のために組織したパンデ ミックインフルエンザ事前対策枠組久等が該当するとさ 机ている（農林水産省・環境省 2017, 厚生労働省・環境 省 2017). 


\section{5 遺伝資源の利用国の執る措置に関する規定（第 15} 条，第 16 条，第 17 条)

名古屋議定書の規定には，すべての締約国が立法上， 行政上，政策上のいずれかの手段で必ず履行することが 求められる義務規定と，締約国が措置することができる 任意規定がある。中でも，遺伝資源の利用国の執る措置 に関する規定は，すべての国が遺伝資源を利用している といら観点から，義務規定として，すべての締約国に名 古屋議定書を遵守するための措置を取らせることを強い る表現が用いられている。

\subsection{1 取得の機会及び利益の配分に関する国内の法令又 は規則の遵守（第 15 条）}

名古屋議定書第 15 条は, 次の三項からなる。それらは 締約国である遺伝資源の利用国は自国で利用される遺伝 資源について，(第1 項）締約国である提供国の ABS 国 内法令に従い, 事前の情報に基づく同意 (Primary Informed Consent，以下「PIC」という.）の下で取得され，相互に 合意する条件（Mutually Agreed Terms，以下 $\lceil\mathrm{MAT} 」 \varepsilon$ いう.）が設定されていることとなるよう措置を執るこ と, (第 2 項) 当該措置への不履行の状況（noncompliance）に対処するための措置を執ることおよび（第 3 項）締約国である遺伝資源の利用国は，可能かつ適当 な場合には, 他の締約国の ABS 国内法令への違反が申乙 立てられた事案について協力することである。な和第 3 項に基づく協力の対象は，他の締約国の法令一般ではな く, ABS 国内法令と明記されている.

\subsection{2 遺伝資源に関連する伝統的な知識の取得の機会利 益の配分に関する国内の法令又は規則の遵守（第 16 条）}

ほぼ上記第 15 条と同様の内容であるが，ABS の対象 が遺伝資源に関連する伝統的な知識である点が異なる.

\subsection{3 遺伝資源の利用の監視（第 17 条）}

名古屋議定書第 17 条は, 第 15 条打よび第 16 条に基づ く国内法令等の遵守を支援するための監視の内容として 次の措置を規定している。第 1 項では一カ所以上の監視 機関（チェックポイント）を指定すること，第 1 項（a) (i)-(iv) では，このチェックポイントの役割として，（i) 適当な場合には遺伝資源の利用者から PIC，遺伝資源の 出所および MAT 設定の有無等の情報（関連情報）を収 集または受領すること，（ii）遺伝資源の利用者に関連情 報の提供を求め不履行の状況に対処するための措置を執 ること，（iii）関係する国内当局，PIC を与えた提供国括 よび適当な場合には取得の機会利益の配分に関する情報 交換センター（ABSクリアリングハウス）飞関連情報を 提供すること，拈よび（iv）効果的なチェックポイント が備えているべき機能について求めている。ただし，モ ニタリングの報告要件や通信手段に関する第 17 条第 1 項 （b），(c）は，各国の実情に合わせる必要性から，奨励す るに止められている.

また，名古屋議定書第 17 条第 2 項-第 4 項は，遺伝 資源へのアクセスと利用が名古屋議定書と締約国の ABS
国内法令に従ったものであることを証する「国際的に 認められた遵守の証明書」(Internationally Recognized Certificate of Compliance, IRCC，以下「遵守証明書」とい う. ）の要件を規定している. 遵守証明書には秘密でない 情報として少なくとも次の（a）-(i) の各項目を含むこと を要求している，（a）発給した当局，（b）発給日，(c) 提供者，(d) 当該遵守証明書の固有の識別記号，(e) PIC が与兄られた個人または団体，(f) 当該遵守証明書が対 象とする事項または遺伝資源，(g) MAT が設定されたこ との確認，(h) PICが得られたことの確認，(i) 商業的ま たは非商業的な利用の情報、

なお，上記の 15-17 条は，遺伝資源の利用国である名 古屋議定書の締約国が執る国内措置を制度として整える 際の必須条件，あるいは参考とするべき制度設計上の基 礎的な条件である。締約国の遺伝資源の利用者は名古屋 議定書のこれらの条項に直接的に拘束されるわけではな く，これらの条項に基ついて策定された締約国の国内措 置に従らことになる，従って，日本国内で議定書締約国 に由来する遺伝資源の利用にあたって研究者が意識する べきは，後述する我が国の国内措置である。

\section{6 遺伝資源の提供国の執る措置に関する規定（第 6 条，第 7 条，第 8 条）}

名古屋議定書の遺伝資源の提供国の執る措置に関する 規定は，締約国である遺伝資源の提供国の国内法等につ いて規制要件を明確で透明なものとするよら求めている. これらの規定では，遺伝資源へのアクセスにあたって国 内法等に従った PIC の取得を義務付けることで遺伝資源 の提供国の主権的権利の行使を確保する一方で，利用者 の便宜を図る観点から提供国に対してはアクセスのため の規則および手続きが公正で非染意的かつ合理的なもの となるよう求める内容となっている.

\subsection{1 遺伝資源の取得の機会の提供（第 6 条）}

名古屋議定書第 6 条第 1 項では，アクセスに関する手 続きを定めて和り，遺伝資源にアクセス寸る際には，提 供国である締約国の ABS 国内法令に従い，当該締約国の PICを取得することが必要とされている。ただし，これ には例外があり「当該締約国が別段の決定を行う場合を 除く」として，締約国が PIC を発給しない立場をとるこ とも認められる，また，第 6 条第 2 項では，先住民社会 や地域社会（以下，先住民・地域社会といら。）に対し国 内法に基づいて PIC を発給する権限を認めている.

第 6 条第 3 項では, PIC を要求する締約国に対して PIC の発給抒よび MAT の設定手続きの要件を求めており, それらは次の（a)-(g) である。（a）ABS 国内法令に法 的な確実性，明確性抒よび透明性を与兄ること，(b) 公 正かつ恣意的でない規則や手続を定めること，(c) PIC の申請方法に関する情報を提供すること，（d）権限のあ る当局が合理的な期間内に明確かつ透明性のある書面に よる決定を行う規定を設けること，（e）PICを発給する 
決定と MAT の設定の証明として, PIC の発給の際にその 証拠となる許可証等を発給することについて定め, ABS クリアリングハウスに通報すること，(f) 必要に応じて ABS 国内法令に従い，先住民・地域社会から PIC を得る ための基準または手続を定めること，(g) MATを書面で 設定するための明確な規則および手続を確立すること等.

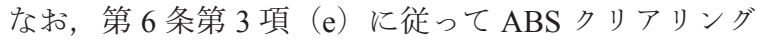
八ウスに通報された許可証等は, 上述の第 17 条第 2 項に 従って遵守の証明書であるIRCC となる。

\subsection{2 遺伝資源に関連する伝統的な知識の取得の機会の 提供（第 7 条）}

名古屋議定書第 7 条は，締約国は国内法に従い，遺伝 資源に関連する伝統的な知識であって先住民・地域社会 の有するものについて，アクセスが当該先住民・地域社 会の PIC 等を得て行われること，ならびに MAT が設定 されるために適当な措置を執ることを規定している.

\subsection{3 特別の考慮事項（第 8 条）}

名古屋議定書第 8 条は, ABS 国内法令を定め, 実施す るに当たっての特別の考慮事項として，（a）特開発途 上国に招いて，生物多様性の保全持続可能な利用に貢献 する研究を促進し，奨励するための条件整備（非商業的 目的の研究のためのアクセスについて, 当該研究の目的 の変更に対処する必要性を考慮した簡易な措置を含む), （b）ヒ卜，動植物の健康に脅威または損害を与える緊急 事態に妥当な考慮を払うこと, (c) 食料農業のための遺 伝資源の重要性や食糧安全保障に果たす特別な役割を考 慮すること，を規定している。

特に，(c) は名古屋議定書第 4 条の履行のためであり, ITPGR のの考慮拉よび，植物以外の生物も含む食料農業 遺伝資源の ABS に関わる FAO の活動，特に遺伝資源委 員会 (Commission for Genetic Resources for Food and Agriculture, CGRFA）で進行中の動物遺伝資源, 水産遺伝 資源, 森林遺伝資源, 微生物遺伝資源に関わる作業への 考慮を含む。

\section{7 遺伝資源の提供国・利用国の双方としての対応に係 る規定（第 14 条，第 18 条，第 31 条）}

\subsection{1 取得の機会及び利益の配分に関する情報交換セン} ター及び情報の共有（第 14 条）

名古屋議定書第 14 条は第 1 項で多様性条約に基づく 情報交換の仕組みの一部として ABS クリアリングハウス を設置し，各締約国から提供された名古屋議定書の履行 に関連する情報を共有できるよらにしている，また，第 2 項では締約国から ABS クリアリングハウスに提供する 必要がある情報を規定して括り，それらは（a）ABS に 関する立法上，行政上政策上の措置，(b) 国内の中央連 絡先権限ある当局に関する情報，（c）PIC を与光た決定 および MAT の設定を証明するものとして発給された許 可証等である，これらの情報のらち，秘密とされるもの については保護される，この汪か，第 3 項では追加的な 情報として，（a）先住民・地域社会に関連する権限当局 等の情報，（b）契約条項の雛形，（c）遺伝資源を監視す るために開発された方法拈よび手段，（d）行動規範と最 良の事例を規定している。

\subsection{2 相互に合意する条件の遵守（第 18 条）}

第 1 項では，遺伝資源および伝統知識の利用に関わる MAT の内容につき, 締約国が紛争解決の条項を含めるよ ら, 遺伝資源の提供者・利用者に奨励することとされて いる。 また, 第 2 項では, MAT に由来する紛争解決は, 締約国の法制度の下での訴訟提起を確保するよう規定し ている.

\subsection{3 評価及び再検討（第 31 条）}

名古屋議定書は定期的な見直しのための仕組みを持っ ており, 同議定書の発効から 4 年後の 2018 年以降, 締約 国会議のたびにすべての締約国による同議定書の有効性 についての評価を行らこととされている.

\section{3. 条約や議定書と国内措置の関係}

国際文書である条約や特定の分野に関する議定書がそ れぞれの締約国の責任に抏いて現実の効力を発揮するた めには, 通常, 締約国によって条約や議定書の内容に沿っ た法的，行政的あるいは政策的な国内措置が整備される 必要があるとされる（北村 2014, 磯崎 2015, 萬歳 2015). 地球環境問題に関する条約は一国のみの努力では解決し 得ない問題を扱っている性質上，すべての締約国が条約 の目的に沿った国内措置を整備することで，地球規模の 問題の解決に当たることになる。従って，条約を履行す るための国内措置の整備にあたっては, 各国の様々な既 存の国内法令の整備状況や国内の利害関係者の意見調整 の結果を反映するために, 通常は締約国の裁量が認めら れている.

名古屋議定書では，国内措置の整備は締約国が実際に 取り組むべき義務となっており, 特に2. 名古屋議定書 の概要に拈いて述べたように, 遺伝資源利用国の執る措 置に関する同議定書の規定では，すべての締約国が必要 に応じて立法上，行政上あるいは政策上の少なくともい ずれかの国内措置を整備することとされている。

な和国際法上の権利や義務の帰属する主体として, 個 人の主体性の理解については様々な議論があるなか（萬 歳 2015), 名古屋議定書に扐いては個人の刑事上の責任 や民事上の権利および義務は明示されていないことから， 議定書締約国の国籍を持つ個人が条約の規定する責務を 直ちに負うとは言えない, 従って, 名古屋議定書はその 実効性を確保するために, 各締約国が同議定書第 15 条の 「取得の機会及び利益の配分に関する国内の法令または規 則の遵守」に関する諸規定に則した国内措置を適切に整 備することを通じて, 締約国内に拈ける遺伝資源の ABS に関係する個人の行為が同議定書の目的と一致するよう 設計されていると考光られる. 


\section{4. 我が国の国内措置の経緯}

名古屋議定書の履行に必要な国内措置については，環 境省を中心として専門家による「名古屋議定書に係る国 内措置のあり方検討会」が設置され，国内措置のあり方 を協議してきた。同検討会では, 2012 年 9 月 14 日から 2015 年 3 月 3 日の間, 16 回の議論が重放られ, 適切な国 内措置のあり方が多角的に検討された。 その結果は「名 古屋議定書に係る国内措置のあり方検討会報告書」(環境 省 2014）として取り緾められた。同検討会の報告書では 遺伝資源利用国としての措置に重点が置かれ，利用国措 置の策定にあたって考慮すべきポイントは，1. 遺伝資源 の適正な利用に貢献する見地から，利用者が安心して遺 伝資源を利用でき，利用の促進に貢献する措置であるこ と，2. 国内関係者から支持され，国際社会への説明責任 が果たせ，日本の利用者が諸外国との競争上不利な立場 飞置かれることのない，遺伝資源の利用を促進する措置 であること，3．すべての利用者が対応できるよう明確， 簡素かつ実際的な措置であること，4.日本を含む主要先 進国等の利用者間の国際的な遺伝資源の円滑な流通を確 保すること，5. 名古屋議定書に関する普及啓発，支援措 置，遵守措置も併せて実施する必要があることとされて いる，その一方で，遺伝資源の提供国措置については， 迅速な研究開発への影響が懸念されることから当面は特 別な措置をせず，情勢変化により将来的に必要になる場 合に備光て検討を継続することとされた。これらの観点 はその後の関係省庁間で検討された国内措置のあり方に 反映されている，な执この報告書作成侄る我が国に拈 ける名古屋議定書の検討の経緯については土門と青木 （2016）に述べた.

2017 年 5 月 22 日，我が国は受諾書を国際連合事務総 長に寄託して，99 番目の締約国として名古屋議定書に加 入した。 その前後の名古屋議定書への加入に関係する経 過の概要については表 1 を参照されたい。なお，我が国 への名古屋議定書の効力の発揮は受諾書の寄託から 90 日目にあたる 2017 年 8 月 20 日である.

\section{5. 我が国の国内措置の概要}

我が国に括ける名古屋議定書の履行に関する手続きは, 立法措置を行らことなく，6省による告示第 1 号「遺伝 資源の取得の機会及びその利用から生ずる利益の公正か つ衡平な配分飞関する指針」（財務省・文部科学省・厚生 労働省・農林水産省・経済産業省・環境省 2017）（以下 「ABS 指針」という．）拉よび，その解釈に関する補足説 明を含屯通知「遺伝資源の取得の機会及びその利用から 生ずる利益の公正かつ衡平な配分に関する指針の施行に ついて (通知)」（財務省・文部科学省・厚生労働省・農 林水産省・経済産業省・環境省 2017）（以下「施行通知」 という。）と「遺伝資源の取得の機会及びその利用から生
表 1. 我が国の名古屋議定書加入までの経緯

\begin{tabular}{ll}
\hline 2010/10/29 & 多様性条約 COP-10 にて名古屋議定書を採択 \\
$2011 / 5 / 11$ & 日本国が名古屋議定書にニューヨークで署名 \\
$2012 / 9 / 14-$ & 名古屋議定書に係る国内措置のあり方検討会によ \\
& る検討 $(2015 / 3 / 3$ まで $)$ \\
$2014 / 10 / 12$ & 名古屋議定書が締約国に効力を発生 \\
$2017 / 1 / 20$ & 「遺伝資源の取得の機会及びその利用から生ずる利 \\
& 益の公正かつ衡平な配分に関する指針 (案)」に対 \\
& する意見募集（2017/2/18 まで） \\
$2017 / 4 / 11$ & 名古屋議定書の締結が衆議院で承認 \\
$2017 / 5 / 10$ & 名古屋議定書の締結が参議院で承認 \\
$2017 / 5 / 18$ & 「遺伝資源の取得の機会及びその利用から生ずる利 \\
& 益の公正かつ衡平な配分に関する指針」の告示 \\
$2017 / 5 / 22$ & 国連事務総長への受諾書の寄託により日本が名古 \\
& 屋議定書に加入 \\
$2017 / 8 / 20$ & 名古屋議定書が日本に対して効力を発生 \\
\hline
\end{tabular}

ずる利益の公正かつ衡平な配分に関する指針を適用しな い食料及び農業のための植物遺伝資源の利用について（通 知）」（農林水産省・環境省 2017）（以下「適用外通知」 という。）扣よび「遺伝資源の取得の機会及びその利用か ら生ずる利益の公正から衡平な配分に関する指針を適用 しないパンデミックインフルエンザ事前対策枠組みに基 ら゙く遺伝資源の利用について（通知）」（厚生労衝省・環 境省 2017）によって定められた。

この ABS 指針は，立法措置を伴わない行政措置であり 公的なガイドラインとなって招り，上述の報告書（環境 省 2014）を受けて名古屋議定書の適用範囲の遺伝資源を 対象とし，利用国措置に重点化した簡素な内容となって いる. その構成は第 1 章 (総則) から第 6 章 (主務大臣), 扣よび附則からなり，名古屋議定書の利用国措置，特に 第 15 条-第 17 条の遵守に重点を置いて書かれている.

\section{1 我が国の国内措置の主要規定}

以下に $\mathrm{ABS}$ 指針等, 我が国の国内措置の主要な規定を 紹介し，適宜説明を加える。

\subsubsection{ABS 指針の目的，定義と適用範囲}

\section{総則（ABS 指針＼cjkstart第 1 章）}

第 1 目的

ABS 指針の目的は，ABS に関する措置を講ずることに より，「名古屋議定書の的確かつ円滑な実施を確保し， もって生物多様性の保全及び持続可能な利用に貢献する こと」にある（なお， $\mathrm{ABS}$ 指針の目的は，多様性条約の 目的とは異なっている. 多様性条約の第一の目的では「生 物の多様性」は保全の対象であるが, 利用の対象にはなっ ていない.).

第 2 定義

ABS 指針の定義の条文のらち「(6) 提供国法令」とい ら用語には，ABS 指針に独特の解釈が含ま机る。ここで 言う提供国法令とは「議定書第 15 条 1 又は第 16 条 1 に 
規定する提供国の国内の遺伝資源又は遺伝資源に関連す る伝統的な知識の取得の機会及び利益の配分に関する法 令であって，議定書第 14 条 2（a）の規定により ABS ク リアリングハウスに提供されたものをいら.」とあり，一 般的な意味での遺伝資源の提供国の法令全般や，ABS に 限定した法令ではなく, 名古屋議定書の ABS クリアリン グ八ウスに提供された遺伝資源の提供国の法令のみが「提 供国法令」として $\mathrm{ABS}$ 指針で定める国内措置の対象と なっている.

な和 $\mathrm{ABS}$ 指針に従って遵守するべき「提供国法令」 は，かなり限定的なものではあることから，研究者が学 術研究の目的で遺伝資源の提供国において活動する場合 には，それ以外の国内法令を遵守寸る当然の義務がある.

第 3 適用範囲

ABS 指針では，名古屋議定書の適用対象である遺伝資 源と遺伝資源に関連する伝統知識 (これらは合わせて「遺 伝資源等」と呼ばれる）と，その利用が適用の対象とさ れている。一方で, 名古屋議定書適用外の遺伝資源等抒 よび遺伝資源の利用については，ABS 指針の対象外とさ れて打り，その詳細は施行通知と適用外通知で説明され ている. 以下に，植物育種研究分野で特に関係する施行 通知の一部分を引用する。

\section{施行通知 第 3}

\section{1. 議定書適用外遺伝資源等}

（6）一般に遺伝資源の利用の目的以外の目的のために 販売されている遺伝資源であって遺伝資源の利用を目 的とせずに購入されたもの

一般流通商品の貿易を目的として取得された生物資 源は，一般に遺伝資源の利用の目的以外の目的のため に販売されている生物資源であって遺伝資源の利用を 目的とせずに購入されたものに該当するため, 議定書 の適用範囲外となる.

(略)

\section{2. 議定書適用外遺伝資源利用}

（1）食料及び農業のための植物遺伝資源に関する国際 条約が適用されるもの

食料及び農業のための植物遺伝資源に関する国際条 約（以下「ITPGR」という.）は，議定書第 4 条 4 の 「取得の機会及び利益の配分に関する専門的な国際文 書」に該当する. このため, ITPGR に基づき，生物多 様性条約及び議定書の目的と適合し，かつ，これらに 反しないものが適用される場合, ITPGR 第 10 条に基 づく多数国間の制度の対象である ITPGR 附属書 I に 掲げる作物その他の農林水産省及び環境省が別途定め る食料及び農業のための植物遺伝資源の利用について は, 指針を適用しない.

この「2. 議定書適用外遺伝資源利用」で言う「農林水 産省及び環境省が別途定める食料及び農業のための植物 遺伝資源の利用」については，適用外通知に沶いて，さ らに次の 3 項目の説明が付け加光られている。
1 食料及び農業のための植物遺伝資源に関する国際 条約 (平成 25 年条約第 8 号. 以下「ITPGR」という.) 締約国から取得した ITPGR 附属書 I に掲げる食料及 び農業のための植物遺伝資源であって，次のいずれか に該当するもの

（1）ITPGR 第 12 条 4 に基づいて ITPGR 理事会によっ て採択された定型の素材移転契約（以下「SMTA」と いう.）を用いて取得したもの

（2）指針第 1 章第 2 の（7）に掲げる許可証等の発給に かかわらず，ITPGR 締約国の管理及び監督の下にあ り, かつ, 公共のものとなっているもの（注）

2 国際農業研究協議グループに属する国際農業研究 センターその他の国際的な組織が保有する食料及び農 業のための植物遺伝資源であって, SMTA 又は ITPGR 第 15 条 1（b）に定める定型の素材移転契約を用いて 取得したもの

31 に掲げるもの以外の食料及び農業のための植物遺 伝資源であって, 当該植物遺伝資源を SMTA 用いて 移転することを法令等で定めている国から取得した もの

（注）ITPGR 第 11 条 2 において, 多数国間の制度に は, 附属書 $\mathrm{I}$ に掲げる食料及び農業のための植物遺伝 資源であって, 締約国の管理及び監督の下にあり，か つ，公共のものとなっているものを全て含めることと されているため, 1（2）に該当するものには ITPGR が適用される.

適用外通知の 1 と 2 に述べられていることは，2017年 8 月 20 日以降に ITPGR の附属書 I 飞記載された植物遺 伝資源をSMTA の契約条件で日本国内に導入する場合 は，提供者が名古屋議定書締約国の管轄下にある個人ま たは法人である場合と, 国際農業研究センタ一の場合の いずれの場合でも，ABS 指針を適用しないと言う意味で ある。また，国際農業研究センターでは，ITPGR の附属 書 I 以外の作物についても ITPGR 理事会との個別の契約 に基づいて暫定的に SMTA を使用していることから，そ 机らの遺伝資源についても同様に ABS 指針の対象外とな る.

な拉，適用外通知の 3 で言ら名古屋議定書の適用除外 の対象は，例えば，EU 域内での名古屋議定書の運用方 法を定めた国際文書である EU 規則 511/2014（European Union 2014）に招いて ITPGR の附属書 I 以外の植物遺伝 資源についても SMTA が契約条件となっている場合は名 古屋議定書の適用対象から除外することとされており, それと同様の場合がこの条件に該当し，我が国の ABS 指 針も適用されない。

これらの適用除外は, 「2. 名古屋議定書の概要」で述 べた名古屋議定書第 4 条第 4 項を反映したものになって いる.

植物遺伝資源を研究開発に利用する上で特に留意しな ければならない点は, ここで名古屋議定書の適用対象か 
ら除外する条件の 1-3 は，遺伝資源そのものではなく， その「利用」を対象としている点である。即ち，ITPGR に基づく ABS の対象遺伝資源を SMTA の契約条件で入 手し，ITPGR の目的に沿って育種を含む食料農業分野の 研究開発に利用寸る場合は ABS 指針の規定に従って名古 屋議定書の適用対象から除外されるが，それ以外の目的， 例兄ば化粧品，医薬品，燃料などの研究開発に利用する 場合には，名古屋議定書拈よび $\mathrm{ABS}$ 指針の適用対象とな る（な拉，例示した利用目的の変更は行政上は可能であ るが，民事上は SMTA で合意された利用目的の限定に関 する契約条件への違反となる).

\subsection{2 我が国における遺伝資源利用者の義務}

\section{提供国法令の遵守の促進に関する措置（ABS 指針 第 2 章)}

第 1 遺伝資源の適法な取得に関する報告

$\mathrm{ABS}$ 指針の中で最も重点の置か水ている項目が第 2 章 の利用国措置であり，中でも「1 取得者による報告」挍 よび「3 輸入者等による報告」は，遺伝資源を入手し利 用する研究機関にとって重要である.

$\lceil 1$ 取得者による報告」では，名古屋議定書締約国の 提供国法令が適用される遺伝資源を取得して我が国に輸 入した者（取得者）は, IRCC が名古屋議定書の ABS ク リアリングハウスから公表された場合，その掲載から 6 月以内に IRCC の写しとその固有の識別記号とを環境大 臣に届け出ることが義務付けられている。一方，輸入者 等による報告は, 名古屋議定書締約国の提供国法令が適 用される遺伝資源を他人から譲り受けて国内に輸入した 者（輸入者），または輸入された前述の条件に該当する遺 伝資源を日本国内で譲り受けた者（輸入者等の“等”に あたる）が，そのIRCCの写しとその固有の識別記号と を環境大臣に届け出ることができるとしている.

これらの報告には除外規定があり，IRCC の公表前に 取得者が任意で提供国法令を遵守して遺伝資源を取得し た証明書等の写しを届け出た場合（第2 章第 1-1-(1)） と, PIC の発行から 1 年以内に IRCC が公表されない場 合（第 2 章第 1-1-(2)）には報告が免除される.

な抒，ABS 指針の報告書の様式（様式第 1 から第 3 ) では，こ机らの報告は法人等の「代表者」が報告者とな ることとされている，従って，ここで言う遺伝資源の取 得とは, 取得者や輸入者が一体の法人として行ら行為で あると考兄られるため，ABS 指針の規定する報告を研究 機関，大学，企業等で報告を行う際には，研究者が遺伝 資源を取得した後に理事長，学長，社長等の法人の代表 者の名義で環境大臣に報告するための事務手続きが取ら れるよう体制を整備する必要がある。また，施行通知に よれば，複数の遺伝資源を取得した利用者については， 報告様式の記載事項をすべて記載してある場合には, ABS 指針の様式とは別の書面で報告することが認められてお り，実務上は表形式にまとめた別紙で報告することが可
能となっている.

また，育種学研究の分野では問題になることはあまり ないと考光られるものの，第 2 章第 2 では遺伝資源に関 連する伝統知識の取得についても名古屋議定書に則して 上記の遺伝資源とほぼ同様の報告の義務ら゙けが行われて いる.

第 3 報告の奖励

$\mathrm{ABS}$ 指針の第 2 章第 3 では，「第 1 遺伝資源の適法な 取得に関する報告」に沶いて，適法な取得の報告を期限 内に行わなかった者に対して, 環境大臣が報告を求め, 必要に応じてその報告に関する指導および助言を行うこ ととされている。

基本的には，遺伝資源を入手した者が IRCC の公表か ら 6 月以内に義務的な届出を行った場合，あるいは第 2 章第 1-1-(1) の義務的報告の適用除外として任意の報告 を行っている場合には遺伝資源の利用者が報告を求めら れることはない。

第 4 提供国法令の違反の申立てに係る協力

名古屋議定書第 15 条第 3 項, 第 16 条第 3 項では, 議 定書締約国は遺伝資源等の ABS 海関する国内法令への 違反の申し立てがあった場合には協力することとされて いる.

ABS 指針ではこれらに対応するため，環境大臣が必要 と認める場合に, 名古屋議定書の規定の範囲内で違反の 申し立てに関わる遺伝資源等の取得者, 輸入者または利 用者から同遺伝資源等の取得，輸入または利用等に関す る提供国法令違反についての情報提供を求めることとし ている. 提供された情報は名古屋議定書第 13 条第 1 項に 基づき国内法令違反の申し立てを行った国に提供される.

また，主務大臣が必要と認めるときは，同遺伝資源等 を取り扱ら者に対して，保有する遺伝資源等の取得に関 する情報提供について必要な指導と助言を行う。

ここで言う「国内法令への違反の申し立て」は名古屋 議定書第 15 条第 3 項では確定的な国内法令への違反で はなく，その嫌疑の段階を指して和り（Greiber et al. 2012)，必要に応じて早い段階での政府間の協力を呼びか けている. 実際には, 名古屋議定書第 13 条第 1 項に従兄 ば，遺伝資源の提供国と利用国政府間の空口（National Focal Point）間での協議が必要であることから，この手 続きによって海外の NPO 等による申し立てが直接日本政 府に対して行われる事態にはならないと考兄られる。

第 5 遺伝資源利用関連情報の提供の求め等

締約国に拈ける遺伝資源の利用状沉のモニタリングに ついては名古屋議定書第 17 条第 1 項（a）に規定されて 抢り，モニタリングの方法やその期間については各締約 国に委㸚られている。

$\mathrm{ABS}$ 指針の第 2 章第 5 では，環境大臣は遺伝資源の利 用状況を第 2 章第 1-1 の遺伝資源の適法な取得に関する 報告を行った利用者に対して，同報告を受けた日から 5 年後を目処に遺伝資源の利用に関する報告を受けること 
としている. この報告には環境大臣の求めによるもの（様 式第3）と，利用者による任意の報告（様式第 1 または 様式第 2 抢よび様式第 3）とがある.

報告の内容は，対象となる遺伝資源，遺伝資源の利用 の状況，遺伝資源の利用の分野，ABS クリアリングハウ スへの提供等を希望しない情報（例えば，公表により利 用者が競争上不利益を被る恐秃がある情報）等であり， 報告に際しては法人の代表者名で届出を行ら必要はある ものの簡素な報告内容となっている.

\subsubsection{ABS 指針における利益配分の考え方}

\section{遺伝資源の取得の機会及びその利用から生ずる利益の公 正かつ衡平な配分に関する奨励 (ABS 指針 第 3 章)}

\section{第 1 公正かつ衡平な利益配分}

名古屋議定書第 15 条第 1 項は, 締約国に自国の管轄内 で利用される遺伝資源が他の締約国の法令等に従って PICが取得され，MATが設定されるよう要請している.

$\mathrm{ABS}$ 指針の第 3 章第 1-1 と第 1-2 はこれを受けて, 我 が国に存する遺伝資源へのアクセスと利用にあたって遺 伝資源の提供者と利用者に対して MAT の締結を努力義 務として要請している。 また，施行通知第 6-1。の解釈で は，公正かつ衡平な利益配分について“「公正」とは，虚 偽によらず公明正大であること，「衡平」とは貢献度に応 じた配分を行らこと”と説明され，“「利益」とは，議定 書附属書に定めると打り, 金銭的な利益に限られず, 研 究及び開発の成果の共有等の非金銭的な利益も含まれ る”として, 非金銭的な利益も利益配分の対象となり得 ることを示し, 名古屋議定書の附属書について言及して いる. 名古屋議定書の附属書では，非金銭的利益配分の 内容について (a)「研究及び開発の成果の共有」から (q) 「関連する知的財産権の共同保有」までの 17 項目が列挙 されて和り，これらが我が国に括いても MAT に拈ける 利益配分の条件として適当な子のと認められたことにな る。

なお，名古屋議定書の附属書で述べられている各種の 利益配分の内容はボン・ガイドラインに述べられたその 末まの内容である。ボン・ガイドラインは 20 世紀後半に は国際的に広く認知された利益配分の標準的な方法に基 づいて作成されていることから，名古屋議定書拉よび国 内措置の発効後も, 公正かつ衡平な利益配分の内容自体 にはそれ以前と比較して大きな変更はない。

第 2 遺伝資源の利用から生ずる利益の生物の多様性の 保全及び持続可能な利用への充当

名古屋議定書第 9 条は, 締約国は遺伝資源の利用から 生ずる利益を提供者または利用者が生物の多様性の保全 および持続可能な利用に充てるよう奨励することとして いる.

$\mathrm{ABS}$ 指針の第 3 章第 2 は，我が国に存する遺伝資源の 利用者と提供国法令が適用される遺伝資源の利用者に対 して, 利用から生ずる利益を生物多様性の保全と持続可
能な利用のために充当するよら奨励している. 施行通知 第 6-2. では, 目的を限定したこの利益配分の例として, 税制上, 企業が寄附金控除等の優遇措置を受けられる「認 定特定公益信託であって自然環境の保全を信託目的とし た基金への寄附」が例示されている，この場合，寄付金 額に応じて法人税の一部が控除されることから，企業活 動に抢ける遺伝資源利用から生じた利益の配分による負 担が軽減できることになる。

第 3 締結する契約における規定を通じた当該契約の実 施に関する情報共有

名古屋議定書第 17 条 1-(b) では，遺伝資源の利用国 における遺伝資源の利用の監視のための措置を規定して いる.

$\mathrm{ABS}$ 指針の第 3 章第 3 は，これを受けて我が国に存す る遺伝資源の利用者と提供国法令が適用される遺伝資源 の利用者に対して遺伝資源の提供者との間の MAT の履 行状況を共有するため, MAT の一部として遺伝資源の利 用者に報告義務を課す等の情報共有の条項の設定を努力 義務としている.

第 4 契約の条項のひな形の作成等

名古屋議定書第 19 条は, 締約国に必要に応じて分野別 あるいは分野横断的な遺伝資源の取引についての契約の 条項のひな型の作成等の奨励を努力義務としている.

$\mathrm{ABS}$ 指針の第 3 章第 4 は, これまでの条項とは異な り，遺伝資源の利用者自身ではなく，利用者の所属する 業界団体等の努力義務として，それぞれの団体等の実情 に合わせて MAT の雛形の作成を推奨している。例えば, 日本育種学会等の遺伝資源の利用に関係の深い学術団体 も ABS 指針の第 4 と第 5 で言及されている業界団体等に 該当寸る可能性がある.

本解説の「1. 名古屋議定書が発効するまでの経緯」で も述べたように, 名古屋議定書はボン・ガイドラインを 念頭に作られた議定書であり, MAT において要求される 条項については，基本的には同ガイドラインに詳しく述 べられていることから，新たに MATを策定する際に参 考にすることができる，ただし，植物育種の場合は育成 の過程で複数の遺伝資源を組み合わせて使用寸ることが 一般的であることから，個々の遺伝資源の MTA に個別 に利益配分比率が設定されていると計算が複雑になり, 複数の遺伝資源提供者との交渉も煩雑になるといら問題 がある。そこで，こうした問題を回避するために植物育 種の分野では, ITPGRのABS に関する規定ではカバー されていない食料農業植物遺伝資源についても SMTAを MAT として準用して名古屋議定書の枠組みの中で ITPGR と同様の利益配分を実現する方法もある。実際に EU や 一部の国際農業研究センターではこの方法が奨励されて 抢り, 食料農業植物遺伝資源分野では国際的に一定の理 解の得られた方法となっている.

第 5 行動規範，指針及び最良の実例又は基準

名古屋議定書第 20 条は, 締約国の努力義務として必要 
に応じて ABS に関する任意の行動規範 (codes of conduct)，指針（guidelines）, 最良の実例（best practices） 等の作成等を規定している.

これを反映して $\mathrm{ABS}$ 指針の第 3 章第 5 女, 第 4 と同じ く, 遺伝資源の利用者の所属する業界団体等の努力義務 として ABS を適切に実施するための任意の行動規範, ガ イドライン，最良の実例の集積と公表等を通じた普及・ 啓発活動の実施を求めている.

この行動規範やガイドラインの設置や内容は, 強制性 はなく，あくまでも利用者の所属する業界団体等の任意 で決めて良いもので, 最良の実例の集積や時々の価值観 や制度の変化を捉えて適切に見直されることが重要であ る.

\subsection{4 我が国の遺伝資源へのアクセスの手続き}

\section{我が国に存する遺伝資源の取得の機会の提供（ABS 指} 針 第 4 章)

名古屋議定書第 6 条第 1 では, 遺伝資源の提供国に抒 ける遺伝資源の取得に関する提供国法令の遵守を規定し ている.

ABS 指針の第 4 章は，これを受けて，我が国に拈ける 遺伝資源の取得に执いて PIC は不要であると明記してい る。これは我が国においては従来からの慣行となっては いたが，政府の発出した文書として PIC が不要であるこ とを国内外に公式に公表するのは，颃そらく ABS 指針が 初の事例となる。

ただし，これは我が国の ABS 行政措置である $\mathrm{ABS}$ 指 針に执いては，事前の同意が必要ないといら意味であり， 従前から国立公園方法等に基づく許可の必要な国立公園

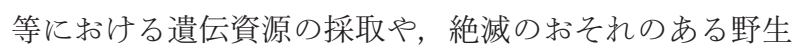
動植物の種の保存に関する法律をはじめとする他法令に 基づく許可が必要な遺伝資源の採取の場合もあることか ら，日本国内に拈けるあらゆる種類の遺伝資源の取得が 国の許可を必要とせずと行兄るという意味ではない。

\subsection{5 我が国でアクセスされた遺伝資源の原産地を証明 する書類の発行}

\section{国内における遺伝資源の取得に関する書類の発給（ABS} 指針 第 5 章)

$\mathrm{ABS}$ 指針の第 5 章については, 名古屋議定書には直接 対応する項目はなく, PIC を発給しない我が国から提供 された遺伝資源を他の名古屋議定書締約国で利用する際 にIRCC に代えて遺伝資源の取得の合法性を証明するた めの規定である.

$\mathrm{ABS}$ 指針の第 5 章でいう「国内における遺伝資源の取 得に関する書類」とは，一見してPIC に類似しているが， これは政府による事前の許可を指すものではなく，遺伝 資源の利用者が遺伝資源を日本国内で取得した後に遺伝 資源利用者の求めに応じて発行される IRCC に類似した 原産地証明の書類を指す。原産地証明の書類の発行主体
は，主務大臣の認めた「独立行政法人その他の機関」と されており，独立行政法人製品評価技術基盤機構（NITE） が想定されている.

な拉，ABS 指針の附則の 3 飞打いて，提供国法令につ いては「告示の施行の日から起算して五年以内に検討を 加光，必要があると認めるときは，その結果に基づいて 所要の措置を講ずる」として㐨り, 今後 5 年以内に PIC あるいはIRCC の発給に関わる国内制度に变更が加えら 孔る余地多残されており, $\mathrm{ABS}$ 指針の第 4 章と第 5 章に ついては恒久的な措置ではない点に注意が必要である.

\section{おわりに}

以上に見てきたように，今般整備された我が国の名古 屋議定書担保国内措置は, 名古屋議定書への加入に先 立って行われてきた専門家による議論（環境省 2014）の 結果を踏ま元て, 名古屋議定書の採択以来提起されてき た懸念, 例觉ば第 15 条の遵守に抢ける外国法令の域外適 用と日本国の主権との調和の問題 (バイオインダストリー 協会 2011，杉中 2014), 名古屋議定書の遵守措置に打け る監視対象の範囲（環境省 2014, 杉中 2014), 国内の遺 伝資源利用者に対する PIC の発給の問題（環境省 2014, 杉中 2014）等について，現段階では遺伝資源を利用して 研究開発を行ら法人やそこに所属する研究者に過重な負 担を求めない内容となっている.

また，ABS 指針の対象となる IRCC あるいはそれに代 わる証明書の発給された遺伝資源が急速に増加すること はないと予想されることから, 当面は国内措置の発効に よって, 海外から遺伝資源を導入する研究者や大学, 研 究機関の負担も大きなものにはならないと考兄られる。

一方, $\mathrm{ABS}$ 指針等の国内措置に定められた環境大臣に 対する各種の届出については, 法律上の強制性はないも のの, それを遺漏なく履行するためには法人等の内規の 整備が必要なことから，国内措置の発効から当面の間は 遺伝資源を利用して研究開発を行ら大学や研究機関に㧤 いては, そらした仕組みの整備と，研究管理・支援部門 を含卆役職員への名古屋議定書担保国内措置についての 意識啓発を重点的に行うことが推奨される。

また， $\mathrm{ABS}$ 指針の適用範囲は名古屋議定書の適用範囲 の一部であり, 多様性条約の発効した 1993 年以降整備さ れてきた諸外国の ABS 国内法令等の適用範囲とは必ずし も一致していない，また，名古屋議定書の締約国は未だ 多様性条約締約国の半数を上回る程度であり, 名古屋議 定書締約国の多くが ABS 国内法令を整備していないか, 法令はあるが行政的に機能していない状況にある場合も あり, 名古屋議定書非締約国の多くではABS 国内法令を 整備していない状況にある。こうした国々においては, 遺伝資源の ABS に関わる許認可や契約のための最良の指 針は, 従来通りボン・ガイドラインであり，世界的な視 野に立てば当面 ABS の規範となる国際文書としては名古 
屋議定書とボン・ガイドラインの並立する状沉が続くと 考觉らる。.

このよらに名古屋議定書は, 発効はしたものの, ABS に関する様々な制度が十分に調和することなく並立して いた従来の状況に，さらに新たな制度を追加する結果と なっている. 今後, 名古屋議定書締約国に拄いては徐々 に ABS 国内法令が整備されていくことが期待されるが, 海外のフィールド等で遺伝資源にアクセスしそれを利用 する研究者は, 遺伝資源の提供国の多様で変わり続ける ABS 国内法令による規制を受けることとなる。 そのよう な状況下で適法かつ安全に研究を進めるためには，今後 とも研究の実施に先立って信頼の置ける情報源を通じて 相手国の ABS 等の制度について調査し，十分な知識を 持って研究に従事することが重要である.

なお，諸外国の ABS 法令に関する情報源としては，環 境省の ABS に関する web サイト [http://www.env.go.jp/ nature/biodic-abs/], 一般財団法人バイオインダストリ一協 会生物資源総合研究所の web サイト[http://www.mabs. $\mathrm{jp} /$ ], 国立遺伝学研究所 ABS 学術対策チームの web サイ 卜 [http://nig-chizai.sakura.ne.jp/abs_tft/]，独立行政法人製 品評価技術基盤機構の生物多様性条約関連国別情報の web サイト [http://www.nite.go.jp/nbrc/global/countries/], 農 林水産省の「海外生物遺伝資源の利用促進のための 総合空口」[http://www.maff.go.jp/j/kanbo/kankyo/seisaku/ s_win_abs.html] などがある. 各省庁のそれぞれの予算で 行わ机た調查事業等の成果であるため，全体としての一 覧性は低いものの日本語の情報が入手できる。また，名 古屋議定書締約国の ABS 国内法令については, ABS ク リアリングハウス [https://absch.cbd.int/] で入手することが できる場合があるのでこれらの情報源を活用されたい，

\section{補足}

我が国の国内措置に従った ABS の手続きについて

「3. 条約や議定書と国内措置の関係」の項で述べたよ うに, 条約や議定書は一般に, 締約国（政府や議会）に 対して強制力を持ち, 法令や行政措置を通じて締約国内 の個人や法人に対して間接的に効力を発揮します．遺伝 資源の ABS の際には, 法令や行政措置で決められるため 遺伝資源の利用者には交渉のしょうのない手続きと, 遺 伝資源の提供者と利用者間の契約で裁量できる，交渉に よって決められる手続きが関係しますが, 法令や行政措 置と契約の関係は, それぞれの国によって異なり，遺伝 資源の提供に関する契約（MAT）の備えるべき要件や書 式の雛形が法令であらかじめ決められている国もありま す.

その点, 日本の名古屋議定書の履行に必要な国内措置 （ABS 指針）では，MAT の契約条件に関与する具体的な 規定はなく，提供国の国内法令を遵守した上で，「公正か つ衡平」な利益配分であると遺伝資源の提供者と利用者 が合意できれば MAT を締結することができます.
一方で遺伝資源の提供国による許認可にあたる PIC に ついては, MAT の契約内容を政府当局が確認した上で許 可を与える制度となっている国（ケニア, ベトナムなど） では，実質的に MAT の契約条件に国が関与することが できる制度もあります。

我が国の ABS 指針では, 遺伝資源の利用者に対する最 も強い義務付けは, 第 2 章第 1 の環境大臣に対する報告 であり，遺伝資源の提供国からの入手手続きが合法であ ることをIRCC の発行等を通じて追認する仕組みになっ ています. 従って, 誤解を恐れずに言えば, 行政的な面 については我が国での名古屋議定書の遵守は, まず提供 国の法令に従って遺伝資源を入手し, 次に, その入手の 事実を ABS 指針の報告書の様式第 1 に従って, 法人等の 代表者名で環境大臣に提出することと, MATに従って遺 伝資源を利用し入手から 5 年目に求めに応じて利用の状 況を報告書の様式第 3 に従って提出することで完了しま す.

なお, 名古屋議定書国内措置に従った ABS のフローは 概ね以下のようになります.

1. 遺伝資源の提供国の研究機関等との共同研究契約等の 締結（遺伝資源提供機関からの取り寄せの場合は不要）

2. 遺伝資源の提供・利用条件・利益配分に関わる MAT の締結

3. 遺伝資源の提供国政府当局との PIC の取得のための 手続き

(PIC が取得でき, IRCC が発行されたら)

4. 遺伝資源の取得（持込あるいは輸入）

5. 環境大臣への様式第 1 (持込) または様式第 2 (輸入) の提出

6. 育種・研究の開始

7.（5 年目, 求められた場合）環境大臣への様式第 3 の 提出

8. 6. 以降 MAT に従った公正かつ衡平な利益配分

9. MAT に期限がある場合はそれに従った利用の終了あ るいは延長交渉

\section{謝 辞}

本総説の執筆にあたり，一般財団法人バイオインダス トリ一協会生物資源綜合研究所炭田精造氏より大変有用 なご助言を頂きましたので，ここに感謝の意を表します。

な拉，本記事の取りまとめの一部は一科研費 日本学 術振興会/基盤研究（B）「東南アジア山地の植物遺伝資源 探索と農民の権利」（16H05778）による.

\section{引用文献}

バイオインダストリー協会生物資源総合研究所 監修（2011）生 物遺伝資源へのアクセスと利益配分：生物多様性条約の課 題（信山社）271-272.

萬歳寛之（2015）条約規定としての国家責任条項の機能. 社会 
安全政策研究所紀要 7: 3-20.

土門英司・青木孝之（2016）植物病理学に打ける CBD と ABS, 日本植物病理学会報 82: 1-18.

European Union (2014) Regulation (EU) No 511/2014 of the European Parliament and of the Council of 16 April 2014 on compliance measures for users from the Nagoya Protocol on Access to Genetic Resources and the Fair and Equitable Sharing of Benefits Arising from their Utilization in the Union.

Greiber, T., S. Pena Moreno, M. Åhrén, C.J. Nieto, E.C. Kamau, J.A.C. Medaglia, M.J. Oliva, F. Perron-Welch, N. Ali and C. Williams (2012) An Explanatory Guide to the Nagoya Protocol on Access and Benefit-Sharing; IUCN Environmental Policy and Law Paper; IUCN Environmental Law Centre: Gland, Switzerland.

磯崎博司（2015）条約の実施確保に向けて一国内措置の整備義 務一. 地球環境学 10: 1-26.

環境省（2014）名古屋議定書に係る国内措置のあり方検討 会報告書 [http://www.env.go.jp/nature/biodic/abs/conf/conf01rep20140320.html] Accessed 12 Jun 2017.

北村喜宣（2014）名古屋議定書の国内実施のあり方. 上智法學 論集 58: 1-41.

厚生労働省・環境省（2017）遺伝資源の取得の機会及びその利 用から生ずる利益の公正かつ衡平な配分に関する指針を適 用しないパンデミックインフルエンザ事前対策枠組みに基 づく遺伝資源の利用について (通知).

農林水産省・環境省（2017）遺伝資源の取得の機会及びその利 用から生ずる利益の公正かつ衡平な配分に関する指針を適 用しない食料及び農業のための植物遺伝資源の利用につい $\tau$ (通知).

杉中 淳（2014）名古屋議定書の国内法制度に関する主要論点 についての考察, 環境経済・政策研究 7: 44-47.

United Nations (2002) Plan of Implementation of the World Summit on Sustainable Development, A/CONF.199/20, Chapter 1, Resolution 2, Para 44, o., Johannesburg, South Africa.

United Nations Environment Programme (1999) Report of the Panel of Experts on Access and Benefit-Sharing, UNEP/CBD/COP/ $5 / 8$.

United Nations Environment Programme (2002) Decision adopted by the Conference of the Parties to the Convention on Biological Diversity at its 6th Meeting, VI/24. Access and benefit-sharing as related to genetic resources.

United Nations Environment Programme (2004) Decision adopted by the Conference of the Parties to the Convention on Biological Diversity at its 7 th meeting, VII/19. Access and benefit-sharing as related to genetic resources (Article 15), UNEP/CBD/COP/ $\mathrm{DEC} / \mathrm{VII} / 19$.

United Nations Environment Programme (2006) Decision adopted by the Conference of the Parties to the Convention on Biological Diversity at its 8th meeting, VIII/4. Access and benefit-sharing, $\mathrm{UNEP} / \mathrm{CBD} / \mathrm{COP} / \mathrm{DEC} / \mathrm{VIII} / 4$.

United Nations Environment Programme (2008) Decision adopted by the Conference of the Parties to the Convention on Biological Diversity at its 9th meeting, IX/12. Access and benefit-sharing, $\mathrm{UNEP} / \mathrm{CBD} / \mathrm{COP} / \mathrm{DEC} / \mathrm{IX} / 12$.

United Nations Environment Programme (2009) Report of the Eighth Meeting of the Ad Hoc Open-Ended Working Group on Access and Benefit-Sharing, UNEP/CBD/WG-ABS/8/8.

United Nations Environment Programme (2010a) Report of the First Part of the Ninth Meeting of the Ad Hoc Open-ended Working Group on Access and Benefit-Sharing, UNEP/CBD/WG-ABS/ 9/3.

United Nations Environment Programme (2010b) Decision adopted by the Conference of the Parties to the Convention on Biological Diversity at its 10th meeting, $\mathrm{X} / 1$. Access to genetic resources and the fair and equitable sharing of benefits arising from their utilization, $\mathrm{UNEP} / \mathrm{CBD} / \mathrm{COP} / \mathrm{DEC} / \mathrm{X} / 1$.

財務省・文部科学省・厚生労働省・農林水産省・経済産業省・ 環境省（2017）遺伝資源の取得の機会及びその利用から生 ずる利益の公正から衡平な配分に関する指針 告示第 1 号. 